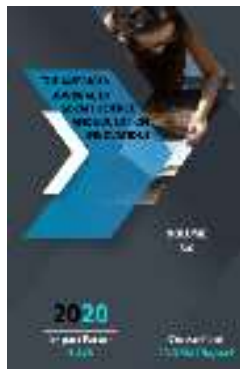

Journal Website: http://usajournalshub.c om/index,php/tajssei

Copyright: Original content from this work may be used under the terms of the creative commons attributes 4.0 licence.

\section{The Role Of Education Reform In Uzbekistan In Reducing Youth Delinquency}

\author{
Tojibayev Bakhromjon Turabayevich \\ Namangan Institute Of Engineering And Technology Department Of "Humanities" PhD In \\ Sociology, Uzbekistan
}

\section{Azimov Ashirali Mexmonboevich}

Teacher Of The Department Of Social Sciences And Humanities, Andijan State Medical Institute, Uzbekistan

\title{
ABSTRACT
}

The article assesses the importance of education in the modern world and its role in reducing youth deviation as a social institution. Education reforms in Uzbekistan emphasize the quality of reducing the deviation of young people by increasing the efficiency of "human capital".

\section{KEYWORDS}

Education, human capital, education reform, youth, conformity, deviation, delinquency

\section{INTRODUCTION}

The role of education in ensuring the social development of a society is very important. Education, as an important part of the formation of human capital, plays a fundamental role in increasing the socioeconomic creativity of the people. Also, as a result of high efficiency of education, the development of the individual's ability to create new ideas becomes a locomotive of social development, ensuring that he is a subject with constructive-innovative qualities, rather than destructive aspects. As the efficiency of education has become a necessity, in our society, as in the rest of the world, the importance of development has increased by increasing the efficiency of "human capital".

In our national encyclopedia, education is described as the process of acquiring knowledge, skills and abilities, as the main 
means of preparing a person for life and work[16:178]. The scientific study of education, which performs institutional functions, is the identification of mechanisms that increase the effectiveness of the interrelated instructions and relationships of the complex social environment in the education system. It is education that is "responsible" for our future, it is education that is "the agent of the future in the present." According to sociologists, in the modern world, education has become the "key" to a new level and success. From the second half of the XIX century there was a kind of "boom" in the requirements for education[5:232]. Also, according to international experts, the results of educational reforms should be replaced by "ecologocal man" in the future[1:113]. In this regard, in Uzbekistan, priority is given to educational mechanisms based on the principles of the idea of a perfect human being and the idea of tolerance as a result of education.

\section{MATERIALS AND METHODS}

Education, as an important socialization agent, plays a key developmental creative role in human development. Just as there is no education without discipline, no education without discipline, no righteous person can be prepared without knowledge and skills. At the same time, education serves as a selector and serves as a key criterion in the formation of students as a conformal or non-conformal person. The main problem here is the owners of unconformal behavior and the factors that cause it. It is important that the head of state also noted the problems in this area: "It is easy to work with talented, educated children, but it is difficult to encourage and persuade young people who stumble or fall into a bad environment"[12:533].

Defining the basic rights of youth and the role of state and public organizations in the development of its Institute of social rights was adapted by result of international year of youth program held by the initiative of the UN in 1985 [7:351-352]. This international document is the program of "The basic tendencies of planning and attempts implemented in the future", and it includes the creation and strengthening antialcohol prevention and prohibition a services. In this regard, the President of the country Sh.M.Mirziyoev proposed to develop a generalized international legal document aimed at the formation and implementation of state youth policy - the UN international convention on the rights of youth[11]. This proposal has aroused interest in the international arena, and its implementation is being carried out gradually. In cooperation with the United Nations, Uzbekistan is working to improve the system of working with children with special needs on the basis of best international practices[18]. From 2019, the Ministry of Public Education began implementing projects to prevent violence in general secondary schools. In particular, the project "Methods of prevention of violence and teaching positive psychology in schools" is planned. A Telegramm-bot (@xtvabbot) has been launched to provide more information about MPE programs to prevent violence in schools. Also, the site http://huquqbuzarlik.uz operates on the basis of a special project on the prevention of deviation among minors in our country

During the post-World War II period of industrialization in our country, the attention paid to education all over the world, especially 
the demand for higher education, increased sharply. According to UNESCO, from 1960 to 1995, the number of students in the world increased from 13 million to 85 million, or 6 times[1:44]. According to a survey conducted by the Public Opinion Research Center in Uzbekistan in 2017, the social significance of education for young people, especially higher education, is growing[2]. The higher education system is also undergoing intensive reforms. According to statistics, in the 2000-2001 academic year, 183.6 thousand students were educated in 61 higher education institutions [3], and in 2019, the country's universities received 128,000 students[4]. In general, the education sector is now at the forefront of reforms in the country, and bold steps are being taken in this direction. Currently, 32 percent of the country's population, or 10 million people, are under the age of 30 [13:13]. In the 2000-2001 academic year, there were 6037.4 thousand students in 9730 secondary schools in Uzbekistan. There were 10090 schools in the 2019-20 school year In 2018630737 children went to school for the first time as students[19].

The last four years have been a turning point in education reform, both in form and content. Recognizing the country's leadership, he noted that the quality of education in the existing professional colleges was not at the level of demand, and the problems in the system were becoming more and more complicated[8]. A number of organizational and structural reforms have been launched in this regard. The President of the Republic of Uzbekistan Sh.M.Mirziyoev criticized the level of knowledge of students studying in the secondary special education system and the problematic aspects of their upbringing, and noted the systemic problems in this area. It was noted that the results of the analysis of the development of general secondary and secondary special, vocational education showed that it does not meet today's requirements and needs radical reform. In particular, it was noted that the organization of the educational process in professional colleges, a superficial approach to the intellectual, spiritual and educational education of students, an ineffective mechanism for occupying their free time will increase the number of offenses and crimes committed by students[15]. In 2010-2014, 21 percent of juvenile offenders were schoolchildren and 43 percent were high school and college students[9:9]. As the head of state said, "Education is not just about school education. Now we are all accustomed to shifting all the blame to school. What about the neighborhood, the family, the general public? The time has come to understand the true meaning of the proverb, "Seven neighborhoods for a child, both father and mother." It is time to realize and live on this basis. But who cares about the fate of the neighborhood today, especially the unorganized youth? Who controls who the children are talking to, when they go to school and when they come? What are the factors behind the increase in hooliganism and crime among young people, especially teenagers?" [17]. These ideas were part of the objective reality of our society. In a 2017 survey conducted by the Public Opinion Research Center, respondents said that the return of the education system to 11 years will improve the quality of the educational process[14].

Young people (young citizens) - persons who have reached the age of fourteen and not older than thirty years[20]. According to statistics, every fourth person in the world is a teenager, making a total of 1.2 billion people between the 
ages of 10-19[21]. So many people are associated with an active learning process or a social institution of education.

People must master the norms and procedures, otherwise it is impossible to think about the perfection of the person. Society requires certain skills and abilities from a person in order to survive. As a result, the rule of law in society, the existing social order serves for development, and the degree to which people adhere to existing laws, social orders, social norms, serves as a necessary criterion for reform. Social norms in educational institutions, which are the creators of the creative generation, students who follow the rules will develop constructive behavior in the future society, and if not, will have a destructive effect on society. Just as there is no profession that does not require competence, young people have the ability to engage in a particular activity, but they do not have the opportunity to engage in a specific and appropriate activity. The ability of young people is also manifested through education and employment. Often during adolescence, young people overestimate their abilities and talents, want to praise themselves, while others look with disbelief at his strength, will, and ability. They also strive to gain recognition from high-ranking members of the public, or at least their peers, no matter what. But often there are cases of irresponsible approach to processes that require willpower, patience and hard work. As a result, adolescents' instinct for faster success becomes a manifestation of globalization at the syndrome level. If a young person's unique abilities are denied by the public or their peers, adherence to conformity and a sense of confidence in the future may decline. This may be the shortest path leads to deviation. In today's societies, the most effective, tried and tested way to address these problems in young people is to get them a steady interest in an activity, have pluralism in society, the existence of various alternative activities, as well as the attractiveness of public life. These include the availability of startups, the need to strengthen various nongovernmental organizations, public associations, the high level of opportunities to help existing categories. Special studies have shown that school-age adolescents need to resolve normal conflicts, identify who they are in this life, monitor their sexual development, and choose a career[10:11].

\section{RESULT AND DISCUSSION}

According to Edwin Sutherland, a member of the Chicago School of American Sociology, criminal behavior is often learned from primary groups, including peers[6:151]. While the family is seen as the primary social group in society, the peer group is seen as the primary group in educational institutions. During this period, the youth's dependence on a group of peers increases as a result of a decrease of adult control in dominance. In this situation, the assimilation of certain aspects of deviance is reflected in the behavior in the sense of "reflecting or representing the image of power".

Reforms under the influence of the above factors, which make it necessary to accelerate the transition from traditional to modern education, the country is increasingly moving towards greater freedoms for students and institutions, efficiency, integration with foreign countries, the introduction of innovative educational technologies. Today, as a result of the democratization of education and the expansion of opportunities for "qualifying maneuvers" in education, the demand for 
specialists has increased[5:232]. In recent years, the demand for changes in the content and form of educational reforms in Uzbekistan has coincided with the reforms, and the view as a factor in its development was due to similar situations.

\section{CONCLUSION}

In conclusion, the ongoing reforms in the field of education in Uzbekistan have a positive impact on reducing youth delinquency. We must cite the following factors as evidence of our opinion:

Reforms in education in Uzbekistan are aimed at development by increasing the efficiency of "human capital";

In Uzbekistan, the criteria of education based on the principles of secular education and national upbringing, as well as the idea of tolerance, are a priority. This condition encourages patience in young people;

The transition from inefficient secondary special education to general education in Uzbekistan as a result of recent reforms has led to a decrease in delinquency by increasing the incentive for young people to learn;

Socio-economic upheaval has created pluralism, attractiveness in society and strengthened young people's confidence in the future, making it a criterion for their resistance to delinquency;

The country is increasingly moving towards greater freedoms for students and institutions, efficiency, integration with foreign countries, the introduction of innovative educational technologies. As a result, pluralism in education remains one of the factors preventing youth delinquency.

\section{REFERENCES}

1. Abdullaev Yu.N. (2000). Sociopedagogical features of foreign education: experience and principles of development. Ped.science.DS.diss., Samarkand:. p.113.

2. sof.uz. (n.d.). Poll: $76.5 \%$ of Uzbek youth know what their biggest dream is Retrieved November 19, 2020, from https://sof.uz/post/so-rovnoma-76-5foiz-o-zbekistonlik-yoshlarining-engkatta-orzusi-nima-ekanligi-ma-lum-boIdi

3. User, S. (n.d.). Statistika qo'mitasi Higher Educational Institutions (at the beginning of the school year). Stat.Uz. Retrieved November 19, 2020, from https://stat.uz/en/249-ofytsyalnaiastatystyka-en/sotsyalnaya-sferaen/obrazovanye-en/4431-specialsecondary-professional-educationalinstitutions-2

4. Social protection, rights of mother and children. (n.d.). Stat.Uz. Retrieved November 19, 2020, from https://stat.uz/en/181-ofytsyalnaiastatystyka-en/6386-social-protection1

5. Filippov F.F. (1990). Sociological analysis of the problem of education. M. Nauka,. p.280.

6. Giddens E.. Sociology. (2002). tr. N.Mamatov and A.Begmatov. Tashkent: Sharq,. 848 p.

7. Introduction to social work. Teterskiy S.V. (2006). tr. A.Begmatov. Tashkent: Society of Cultural Anthropology,. p.465.

8. ijtimoiy-

fikr.uz/uz/oav_materiallari/navqiron_a 
vlodning_qiziqish_va_ qarashlari _ organildi

9. Criminology. Special part. I.Ismailov, Q.R.Abdurasulova et al .. Tashkent. Academy of the Ministry of Internal Affairs, 2015.p.744.

10. The effect of deviance on academic performance. Nanako Watanabe. B.A. Wichita State University, 2000. p.35.

11. lex.uz/m/acts/3864155

12. Mirziyoev Sh.M. We will resolutely continue our path of national development and raise it to a new level. - Tashkent: NMIU "Uzbekistan", 2017. - P.592

13. Mirziyoev Sh.M. Together we will build a free and prosperous democratic state of Uzbekistan. Speech at the joint session of the chambers of the Oliy Majlis dedicated to the inauguration of the President of the Republic of Uzbekistan. - Tashkent: NMIU “Uzbekistan”, 2016. -P.59

14. nuz.uz/mening-zbekistonim/27026srov-ituvchilar-ohirgi-yillarda-uvchilarorasida-nufuzini-yotmoda.

15. National Database of Legislation, 22.02.2019, No. 06/19/5667/2648

16. National encyclopedia of Uzbekistan. Volume 5 Editorial staff: M.Aminov, B.Akhmedov and others. -Tashkent: "National encyclopedia of Uzbekistan" State scientific publication, 2002. p.867.

17. taraqqiyot.uz/yoshlar-srovnomasinatizhalari

18. uzedu.uz/Xtv/IndexBatafsil/71?ID1=139 4

19. uzedu.uz/Xtv/BarchasiPage/67?tp $=86$

20. Collection of Legislation of the Republic of Uzbekistan, 2016., №37,
Article 426; 2017., №24, Article 487; National Database of Legislation, 24.07.2018, No. 03/18/486/1559

21. $x s . u z / u z k r / p o s t / v i d e o s e l e k t o r-$ iivbuyicha 